Check for updates

1 Guy's and St Thomas' Hospitals, London SE1 9RT, UK

2 Faculty of Medical Sciences, Newcastle University, Newcastle on Tyne, UK

3 AbScent Charity, Andover, UK

4 University of Northumbria, Newcastle on Tyne, UK

5 Institute of Philosophy, Centre for the Study of the Senses, London, UK

claire.hopkins@gstt.nhs.uk Cite this as: $B M J 2020 ; 370: \mathrm{m} 3736$ http://dx.doi.org/10.1136/bmj.m3736 Published: 25 September 2020
MANAGING LONG COVID

\section{Managing long covid: don't overlook olfactory dysfunction}

\author{
Claire Hopkins, ${ }^{1}$ Duika L Burges Watson, ${ }^{2}$ Chrissi Kelly, ${ }^{3}$ Vincent Deary, ${ }^{4}$ Barry C Smith ${ }^{5}$
}

"One of the most distressing aspects of living with long covid is the dismissive attitude of some doctors." ${ }^{1}$ This quote from Paul Garner in The BMJ resonates closely with views expressed by patients coming to terms with persistent olfactory dysfunction as a consequence of covid-19 infection. Loss of smell and taste is one of the most prevalent symptoms of covid $-19^{2}$ and the best predictor of covid status. ${ }^{23} \mathrm{~A}$ substantial proportion of patients experience at least partial recovery of their loss of smell, but 10\% report persistent loss eight weeks after onset. ${ }^{4}$

Parosmia-distortion of the sense of smell that can severely impair appetite owing to familiar foods triggering a foul smell-also seems to be prevalent in patients with covid-19. It had already been reported by more than $50 \%$ of patients with post-viral olfactory loss before the covid-19 pandemic. ${ }^{5}$ A similar disruption to normal life is likely to be found among patients with covid-19.

Greenhalgh and colleagues' otherwise excellent article on the management of post-acute covid-19 emphasises the broad range of symptoms experienced by patients with what has been termed long covid, ${ }^{6}$ but does not mention smell or taste disturbance. A patient led project evaluating covid-19 recovery with a survey found that loss of smell and taste was reported by more than $50 \%$ of respondents; loss of appetite and nausea even more frequently. ${ }^{7}$ The terminology used in such surveys, "loss of smell or taste," probably underestimates the extent and health consequences of parosmia. If we are to provide appropriate support and advice, the questions we put to patients should be reframed as "alterations in smell and taste" to better capture the effect of covid-19 on olfactory and gustatory function. We are currently working with a large group of patients who are struggling to manage their persistent olfactory symptoms and feel that they are being overlooked by the healthcare system. Greenhalgh and colleagues' article suggests that they might be right.

Competing interests: None declared.

Godlee F. Living with covid-19. Editor's choice. BMJ 2020;370:m3392doi: 10.1136/bmj.m3392.

2 Menni C, Valdes AM, Freidin MB, etal. Real-time tracking of self-reported symptoms to predict potential COVID-19. Nat Med 2020;26:1037-40. doi: 10.1038/s41591-020-0916-2. pmid: 32393804

3 Gerkin RC, Ohla K, Veldhuizen MG, et al. Recent smell loss is the best predictor of COVID-19: a preregistered, cross-sectional study. MedRxiv 2020.07.22.20157263 [Preprint]. 2020. doi: https://doi.org/10.1101/2020.07.22.20157263

4 Boscolo-Rizzo P, Borsetto D, Fabbris C, etal. Evolution of altered sense of smell or taste in patients with mildly symptomatic covid-19. JAMA Otolaryngol Head Neck Surg 2020;146:729-32. doi: 10.1001/jamaoto.2020.1379. pmid: 32614442

5 Reden J, Maroldt H, Fritz A, Zahnert T, Hummel T. A study on the prognostic significance of qualitative olfactory dysfunction. Eur Arch Otorhinolaryngol 2007;264:139-44. doi: 10.1007/s00405-006-0157-0. pmid: 17006637
6 Greenhalgh T, Knight M, A'Court C, Buxton M, Husain L. Management of post-acute covid-19 in primary care. BMJ2020;370:m3026. doi: 10.1136/bmj.m3026 pmid: 32784198

7 Assaf G, Davis H, McCorkell A, et al. What does covid-19 recovery actually look like? 11 May 2020. https://patientresearchcovid19.com/research/report$1 /$

This article is made freely available for use in accordance with BMJ's website terms and conditions for the duration of the covid-19 pandemic or until otherwise determined by BMJ. You may use, download and print the article for any lawful, non-commercial purpose (including text and data mining) provided that all copyright notices and trade marks are retained. 